\title{
The Relationship between Trade Openness and GDP Growth Rate: The Case of South Africa (1994Q1-2008Q4)
}

\author{
${ }^{*}$ Teboho Jeremiah Mosikari, Mike Nyamazana Sikwila \\ North West University (NWU), Mafikeng Campus, South Africa \\ *tebza.minus@yahoo.com
}

\begin{abstract}
Despite substantial economic restructuring, South Africa's post-1994 export performance is less than what might have been expected or hoped for. The study examines the trade-openness ledgrowth hypothesis in the South African economy. Further, the study uses conventional cointegration approach called Johansen cointegration technique to determine the long-run relationship between trade openness and GDP growth. The cointegration tests show that there exists long-run relationship between trade openness and GDP growth at 1\% and 5\% significance level. Therefore, the study also applies an error correction model to determine the speed of adjustment and the short-term determinants of GDP growth in South Africa. In considering trade openness measures, it indicates that they are generally less pivotal and have an even smaller effect than had been anticipated. The study also adopts Granger causality tests to examine whether growth in trade openness stimulate GDP growth (or vice versa). The results suggest that in all trade openness measures that are used, there is weak evidence suggesting causality from GDP to exports or vice versa. The study recommends that openness trade policy will be beneficial strategy for South Africa in the long-run. Therefore, it is suggested that the South African government continue the policy of trade openness.
\end{abstract}

Keywords: Trade openness, GDP growth, South Africa, Cointegration

\section{Introduction}

Trade openness is often considered in the sense of an increase in the size of the country's traded sector in relation to total production; it is an acceptable proxy for trade liberalisation (Yanikkaya, 2003). In fact, increasing trade openness often reflects the success of trade liberalisation policies (Sarkar, 2007). Due to the difficulty of measuring openness, different studies have used different measures to examine the effects of trade openness on economic growth. Emma and Samman (2005) argue that reliance on the share of trade in GDP as an indicator of trade openness is highly misleading. Despite the debate on what exactly are measures of trade openness, internationally the work of Mbabazi, Milner and Morrissey (2004) indicates that trade openness is positively associated with the growth of 44 developing countries over 1970-95. Moreover, Anderson (2007) states that over the past 40 years since 1965, there is a one-toone correlation between trade and GDP growth in Asian countries. This, in short, is export-led growth. International trade plays a significant role in the Asians economies while, in South Africa, this is less so. According to Rankin (2001), the trend growth rate for South Africa's real exports has been increasing since 1994 by about 5\%. The author points out that although this is poor in comparison with countries such as Malaysia and Indonesia, it is at least an improvement on the previous period. In 2001, the value of merchandise exports increased by $20.3 \%$. The higher rand value of merchandise exports in the first half of 2002 was related to the sharp depreciation of the external value of the rand in the last quarter of 2001. Reports by South African Reserve Bank (SARB) $(2008,2009)$ indicates that South Africa's exports increased by $8.1 \%$ in 2008 from 2007. Imports also increased by $7.1 \%$ in 2008 from US\$ 81.9 billion in 2007 to US $\$ 87.7$ billion in 2008. Total exports and imports of goods and services in 2007 amounted to $31 \%$ and $35 \%$ of GDP, respectively.

The South African export sector has been characterised by low and fluctuating export growth and exports earnings for the past years. Despite substantial economic restructuring, South Africa's post-1994 export performance is less than what might have been expected or hoped for. Flatters and Stern (2007) indicate that a decade since 1994, South Africa's average export growth fell marginally from $6.2 \%$ to $5.6 \%$. On the import side, Lewis (2001) states that during 1993 and 1997 Import penetration accounted between -43\% and $-52 \%$ of the rise in GDP. He further indicates that relatively low import penetration since 1993 suggests that trade openness has remained relatively resilient in the face of domestic production. The main objective of this study is to investigate the causal relationship between trade openness and GDP growth in the Republic of South Africa for the period 1994Q1 to 2008Q4.Against this background the 
purpose of this study is to answer the following questions: Is there a positive relationship between imports and GDP growth? Does causality exist between exports and GDP growth? Does causality exist between imports and GDP growth? Do exports and imports have any significant effect on GDP growth? More specifically the study has this specific objective are:

- To evaluate the sensitivity of GDP growth to changes in trade openness.

- To establish a long run relationship as well as a short run equilibrium model between trade openness and output growth.

- To determine the causality between trade openness and GDP growth in South Africa.

These specific objectives will be achieved by the application of basic econometric analysis. The findings of the study will assist the South African government in establishing appropriate trade policies in order to encourage institutions to promote their exports. The importance of the study also hinges on its ability to help the Department of Trade and Industry (DTI) in their policy making with regard to export promotions. The study also explores the costs and benefits of trade de-regulation since the ushering of democracy in the country in 1994.The remainder of the paper is as follows: the following section 2 highlight on the literature survey, followed by the research method which is followed by model specification. Where section 5 is empirical results, section 6 gives Johansen cointegration results. Also section 7 gives Granger causality results, followed Section 8 gives Discussion and recommendations and lastly Section 9 is suggestions for further research.

\section{Literature Review}

This section presents the literature review on the relationship between trade openness and GDP growth. The contributions of existing researchers contributed in the study of trade openness and GDP growth in order to recommend informed trade openness policies. Giles and Williams (2000) attempt to provide comprehensive information on the empirical research that investigates the export-led growth hypothesis, and to indicate the range of methods applied to examine this hypothesis. Their study indicates that crosscountry research is possibly flawed; in particular, the positive association that is taken as evidence of ELG is as compatible with GLE or feedback effects. The subsequent time series research attempts to rectify some of the issues with the cross-country work, but is itself fraught with problems. Beko (2003) examines the nature of granger causality between exports, both aggregate and at the sectoral level, and output growth in Slovenia for the period 1992-99. The study reveals that by using the conditional causality technique to explore the nature of the relationship between exports and real output from the analysis, a predominant pattern of a bidirectional nature between GDP and various export variables emerges.

Awokuse (2006) explored the causal relationship between real exports and GDP growth in Japan using data set on a quarterly basis which covers the period 1960:1 to 1991:4. The empirical evidence from Granger causality tests, directed acyclic graphs, and forecast error variance decompositions (FEVD) analyses suggest that the causal relation between exports and productivity was bi-directional for the period 1960-1991. Moreover, Balaguer and Cantavella-Jorda (2004) study structural changes in exports and economic growth in Spain. The analysis uses annual data. The sample period spans from 1961 to 2000. The study finds that there is a long-run relationship among output, aggregate export expansion, and export structural change. The results also indicate that exports are a determinant factor for Spain's real output. Sato and Fukushige (2007) investigate the causal relationships between GNP, exports, and imports by estimating a vector autoregression (VAR) model. The study investigates two hypotheses relating to Korea's economic growth: the export-led growth hypothesis and the import-led growth hypothesis. The study also applies the causality test proposed by Toda and Yamamoto (1995). This test is applicable whether or not there are unit roots or cointegrating relationships between the time series. The study finds that after splitting the sample into periods, there is evidence of import-led growth for the first sub-period, but not for the second sub-period.

Edwards and Lawrance (2006) argue that trade liberalization in the 1990s not only increased imports but, by reducing both input costs and the relative profitability of the domestic sales, also boosted exports. Their study also indicates in particular that gross fixed investment is about fifty percent more import intensive than consumption expenditure. Thurlow (2006) assesses the impact of recent trade liberation on the distribution of incomes and poverty in South Africa. The study employs a dynamic general equilibrium and micro simulation model to assess the effects of trade liberalization. The results indicate that trade policies have not contributed to increasing poverty and that trade-induced technological change has accelerated growth. Since international trade includes both the trade and financial 
dimensions, Loots (2002) tested its effect on the South African economy using the period 1990 to 2001 on a quarterly basis. The regression results of trade openness shows a positive, but relatively small (less than one per cent) impact on GDP. De Jager (2004) conducted a study on aspects of growth empirics in South Africa during 1949 to 2000. The study analyses many variables but for specification on the current study only openness of trade and GDP growth is considered. The question of causality and its direction is best answered by the test for granger causality. The result indicates that all measures of openness are indicative of a causal relationship running from openness to economic growth. In cases where openness is measured as the sum of exports and imports as a percentage of GDP, there is an indication of bidirectional causality.

There are many trade openness measures but Loots (2002)'s study considers only one measure. The study is thus deficient compared to measures used in De Jager (2004)'s study. The other problem with the study is that it includes two structural changes prior and after 1994. Again, the study only tested the oneway effect of trade openness and not granger causality. Flatters and Stern (2007) identify the likely winners and losers from trade and trade reform over ten years. The focus of the study is on the broader trade policy challenges and choices that are faced by South Africa in an increasingly global and competitive world economy. The study indicates that there are all signs of highly successful structural adjustment. Whatever the reasons, there can be no doubt that economic reform and the dropping of sanctions have played a key role and the South African economy appears to have become much better integrated with the global economy. Loots (2002)'s study indicates that trade volume is positively related to economic growth in South Africa. Despite these apparently positive growth aspects of international trade, the empirical verification on the effects of trade on economic growth appears to be mixed. In contrast, Roberts (2000) demonstrates that over the period 1992 to 1997, trade liberalization increased South Africa's trade ratio but a direct relation between this and economic growth appears to be doubtful. This mixed results on trade and growth led Strydom (2003) to revisit the analysis on trade-led growth and determine the transmission mechanism through which trade and economic growth are linked. The analysis shows that the channels through which trade generates growth have dissimilar growth effects. Although trade openness plays a significant role in determining GDP growth, it has its costs and benefits. In determining the causality between trade openness and GDP growth, there is still a lack of literature concerning the causality between two variables in South Africa. In this study, we examine the causal relationship between trade openness and GDP growth during 1994Q1-2008Q4. However, the central contribution of the study is to attempt to augment to the existing literature. In addition, from the South African perspective, studies that have been conducted such as those by Edwards and Lawrance (2006) and Thurlow (2006) are more concerned with trade policy rather than determining the causality between trade openness and GDP growth.

\section{Methodology}

The methodological and analytical basis for this study is drawn from the empirical literature focusing on trade openness and GDP growth. To determine the relationship between trade openness and GDP growth data is based on quarterly form from 1994Q1-2008Q4. The study uses secondary data collected from the South African Reserve Bank (SARB), an official statistical and economic data provider. Following Jin (2003), various sets of measures of trade openness are employed in this study: the first set consists of imports/GDP ratio, and the export/GDP ratio. The second set follows Awokuse (2008) and consists of the absolute values of merchandise and service export and also merchandise and service import. The study employs the Granger causality test which was developed by Granger (1969) where he defines the "arrow of time" to help us identify the difference between cause and effect. According to this approach, a variable $\mathrm{Y}$ is caused by $\mathrm{X}$ if $\mathrm{Y}$ is better predicted from past values of $\mathrm{Y}$ and $\mathrm{X}$ together rather than from past values of $\mathrm{Y}$ alone. Prior to estimation of the model adopted, an Augmented Dickey-Fuller (ADF) test by Dickey and Fuller (1981) will be employed to check for first order unit roots. A cointergration test by Johansen (1991) is also applied to determine whether the variables are cointergrated or not and an error correction model for short run analysis. The study uses computer program Eviews version 3.1 for statistical data analysis.

Model specification: From the empirical literature and the theoretical exposition in the previous chapters, a number of possible proxies to measure trade openness have been suggested. These include ratio of imports, ratio of exports, sum of imports and exports over GDP, real exports of goods and services and real imports of goods and services. To commence with, variables that have been found to be considerable in the previous studies in South Africa are chosen De Jager (2004) and Loots (2002). The 
two variables are exports and exports ratio. The base model is then extended by adding other variables for which data is available. This exercise yielded two possible models which will produce results that are economically meaningful. The reason for estimating two regression equations is to capture various ways of explaining trade openness, and to avoid multicollinearity since the measures of trade openness are manipulated using export and import values.

$G D P_{t}=a_{0}+\beta_{1} M_{t}+\beta_{2} X_{t}+\beta_{3} \operatorname{Kinv}_{t}+\mu_{t}$
$G D P_{t}=a_{0}+\beta_{1} M r a_{t}+\beta_{2} X r a_{t}+\beta_{3} \operatorname{Kinv}_{t}+\mu_{t}$

where GDP is gross domestic product in levels, $\alpha$ and $\beta$ are parameters to be estimated, Mt, Xt, Kinvt, Mra $\mathrm{Xra}_{t}$ and $\mathrm{Kinv}_{\mathrm{t}}$ which are defined as observable variables representing factors affecting gross domestic product in South Africa in year $t$, and $\varepsilon_{t}$ is a random error term with a mean of zero, representing measurement error and unmeasured and immeasurable factors.

\section{Results}

This section presents the results on causal relationship between trade openness and GDP Growth in South Africa for the period 1994Q1-2008Q4. Prior to doing any cointegration or Granger causality analysis, it is essential to check the smoothness of the data. In other words, because the majority of the macroeconomic variables are non-stationary, testing for random walk is needed as a first step. It is therefore, prudent to begin any time series work by first checking the variables for trends. This part of the study is dedicated to testing the order of integration. In other words, each variable is tested for stationarity. The hypothesis that is tested is the null hypothesis of the existence of a unit root (nonstationarity) against the alternative of stationarity (no unit root). Tables 1 below present the results of running $\mathrm{ADF}$ tests on the variables in logarithmic form with trend and intercept, intercept and none.It is vital to note at this point that the order of lag length is determined by using the final prediction error (FPE) criterion, suggested by Akaike in applying the Akaike Information Criterion (AIC). The lag orders have therefore been determined by choosing the smallest lag length such that the residuals of the ADF regression yield empirically white noise.

Table 1: ADF Unit root test of all variables at Levels

\begin{tabular}{|c|c|c|c|c|}
\hline Series levels & Model & ADF Lags & ADF $r_{i}^{i} \mu^{i}$ & $\operatorname{ADF} \Phi_{3} \Phi_{1}$ \\
\hline \multirow[t]{3}{*}{ GDP } & Trend and intercept & 2 & -3.00 & 4.70 \\
\hline & Intercept & 3 & 5.38 & 54.01 \\
\hline & none & 3 & 12.31 & -------- \\
\hline \multirow[t]{3}{*}{$X$ (export) } & Trend and intercept & 0 & $-5.04 * * *$ & $12.73^{* * *}$ \\
\hline & Intercept & 0 & -1.15 & 1.34 \\
\hline & none & 3 & 3.94 & -------- \\
\hline \multirow[t]{3}{*}{ M (imports) } & Trend and intercept & 0 & -1.74 & 1.62 \\
\hline & Intercept & 3 & 1.33 & 3.45 \\
\hline & none & 3 & 3.67 & ------- \\
\hline \multirow[t]{3}{*}{ Xra } & Trend and intercept & 0 & -2.66 & 3.60 \\
\hline & Intercept & 0 & -0.53 & 1.63 \\
\hline & none & 3 & 1.51 & -------- \\
\hline \multirow[t]{3}{*}{ Mra } & Trend and intercept & 0 & -2.22 & 2.55 \\
\hline & Intercept & 1 & -1.66 & 1.54 \\
\hline & none & 3 & 1.67 & -------- \\
\hline \multirow[t]{3}{*}{ Kinv } & Trend and intercept & 3 & 1.25 & 2.86 \\
\hline & Intercept & 3 & 3.54 & 3.49 \\
\hline & none & 0 & 5.46 & ----------- \\
\hline
\end{tabular}

* Statistically significant at $10 \%$ level ${ }^{* *}$ statistically significant at $5 \%$ level ${ }^{* * *}$ Statistically significant at $1 \%$ level 
The results from the above table 1 indicate that the null hypothesis of non-stationarity cannot be rejected for most of the variables in levels form with trend and intercept. Hence, all the variables when tested for stationarity under the assumption of intercept and none are non-stationary in levels form.

Table 2: ADF Unit root test of all variables at first difference

\begin{tabular}{|c|c|c|c|c|}
\hline $\begin{array}{l}\text { Series } \\
\text { First difference }\end{array}$ & Model & $\begin{array}{l}\text { ADF } \\
\text { Lags }\end{array}$ & $\begin{array}{l}\text { ADF } \\
P_{i}^{T} \mu_{i}\end{array}$ & $\begin{array}{c}\text { ADF } \\
\Phi_{3} \Phi_{1}\end{array}$ \\
\hline \multirow[t]{3}{*}{$\Delta \mathrm{GDP}$} & Trend and intercept & 3 & $-8.55^{* * *}$ & $811.54^{* * *}$ \\
\hline & Intercept & 3 & $-8.51^{* * *}$ & $1005.525^{* * *}$ \\
\hline & none & 3 & $-8.60^{* * *}$ & ------- \\
\hline \multirow[t]{3}{*}{$\Delta \mathrm{X}$ (export) } & Trend and intercept & 3 & $-7.81^{* * *}$ & $105.10^{* * *}$ \\
\hline & Intercept & 3 & $-7.90^{* * *}$ & $134.03^{* * *}$ \\
\hline & none & 3 & $-7.98^{* * *}$ & -------- \\
\hline \multirow[t]{3}{*}{$\Delta \mathrm{M}$ (imports) } & Trend and intercept & 3 & $-8.08^{* * *}$ & $99.40^{* * *}$ \\
\hline & Intercept & 3 & $-8.17^{* * *}$ & $126.75^{* * *}$ \\
\hline & none & 3 & $-8.20^{* * *}$ & -------- \\
\hline \multirow[t]{3}{*}{$\Delta \mathrm{Xra}$} & Trend and intercept & 3 & $-6.82^{* * *}$ & $76.37^{* * *}$ \\
\hline & Intercept & 3 & $-6.92^{* * *}$ & $97.45^{* * *}$ \\
\hline & none & 3 & $-6.99 * * *$ & --------- \\
\hline \multirow[t]{3}{*}{$\Delta \mathrm{Mra}$} & Trend and intercept & 3 & $-6.95^{* * *}$ & $46.42^{* * *}$ \\
\hline & Intercept & 3 & $-7.02^{* * *}$ & $59.12^{* * *}$ \\
\hline & none & 3 & $-7.06^{* * *}$ & -------- \\
\hline \multirow[t]{3}{*}{$\Delta$ Kinv } & Trend and intercept & 3 & $-5.18^{* * *}$ & $101.47^{* * *}$ \\
\hline & Intercept & 3 & $-5.20^{* * *}$ & $128.76^{* * *}$ \\
\hline & none & 3 & $-5.24^{* * *}$ & ------- \\
\hline
\end{tabular}

* Statistically significant at $10 \%$ level ${ }^{* *}$ statistically significant at $5 \%$ level ${ }^{* * *}$ statistically significant at $1 \%$ level

The Table 2 above shows that when the ADF test is applied to variables in first differences, under the same assumption of a constant and deterministic time trend, most of the variables become stationary at $1 \%$ level of significance. Overall, the results from the ADF test suggest that the variables are integrated of order one. This implies the possibility of cointegrating relationships among the variables. This implies the possibility of long run relationships among the variables.

Johansen cointegration results: It is very important to mention that although the Engle-Granger procedure has distinct advantages the model has some defects. Several Monte Carlo studies that considered the robustness of the test showed that in general the most standards test are not powerful. It is important to try several tests of cointegration instead of using one single procedure. Thus, the following Johansen cointegration is applied here.

Table 3: Johansen cointegration test GDP, KINV, M and X

\begin{tabular}{lllll}
\hline $\begin{array}{l}\text { Hypothesized } \\
\text { no. of CE(s) }\end{array}$ & Eigen value & $\begin{array}{l}\text { Likelihood } \\
\text { Ratio }\end{array}$ & $\begin{array}{l}\text { 1 Percent } \\
\text { Critical Value }\end{array}$ & $\begin{array}{l}\text { 5 Percent } \\
\text { Critical Value }\end{array}$ \\
\hline None & 0.384 & $72.880^{* *}$ & 54.46 & 47.21 \\
At most 1 & 0.364 & $46.170^{* *}$ & 35.65 & 29.68 \\
At most 2 & 0.279 & $21.259^{* *}$ & 20.04 & 15.41 \\
At most 3 & 0.057 & 3.230 & 6.65 & 3.76 \\
& & & &
\end{tabular}

${ }^{*}\left({ }^{* *}\right)$ denotes rejection of the hypothesis at $5 \%(1 \%)$ significance level

L.R. test indicates 3 cointegrating equation (s) at $5 \%$ significance level

The study confirms the relationship between trade openness and GDP growth by employing Johansen cointegration. Its results are presented in Table 3 and 4 . In the first table, according to the critical values reported by Johansen cointegration, a likelihood ratio and eigen value test statistics provides significant evidence for the existence of cointegrating relationship between trade openness measures such as exports, imports, capital formation and GDP growth. The cointegration exists with 3 cointegrating vectors found for equation (4.1a). Also, positive results are found when trade openness is measured in terms of ratio of exports and ratio of imports, with 2 cointegrating vectors for equation (4.1b). In estimating the error correction model, the expression can be drawn from equations (4.1a) and (4.1b). All the variables 
expressed in first difference and lagged variables are used to reflect the short and long-run parameters. The results for ECM are as follows:

Table 4: Johansen cointegration test GDP, KINV, MRA and XRA

\begin{tabular}{lllll}
\hline $\begin{array}{l}\text { Hypothesized } \\
\text { no. of CE(s) }\end{array}$ & Eigenvalue & $\begin{array}{l}\text { Likelihood } \\
\text { Ratio }\end{array}$ & $\begin{array}{l}\text { 1 Percent } \\
\text { Critical Value }\end{array}$ & $\begin{array}{l}\text { 5 Percent } \\
\text { Critical Value }\end{array}$ \\
\hline None & 0.440 & $66.014^{* *}$ & 54.46 & 47.21 \\
At most 1 & 0.313 & $34.106^{*}$ & 35.65 & 29.68 \\
At most 2 & 0.174 & 13.389 & 20.04 & 15.41 \\
At most 3 & 0.050 & 2.875 & 6.65 & 3.76 \\
\hline
\end{tabular}

*(**) denotes rejection of the hypothesis at 5\%(1\%) significance level

L.R. test indicates 2 cointegrating equation(s) at 5\% significance level

Table 5: Error-correction Model based on equation (4.1a)

\begin{tabular}{llll}
\hline Variable & Coefficient & Std. Error & t-statistics \\
\hline C & -0.030765 & 0.141636 & -0.217211 \\
DLOG_KINV & 0.312779 & 0.100092 & $3.124914^{* * *}$ \\
DLOG_M & 0.225926 & 0.049119 & $4.599535^{* * *}$ \\
DLOG_X & 0.147309 & 0.053825 & $2.736794^{* * *}$ \\
DLOG_GDP(-1) & -0.369590 & 0.100020 & $-3.695153^{* * *}$ \\
M(-1) & -0.025202 & 0.123742 & -0.203664 \\
X(-1) & 0.060724 & 0.140098 & 0.433440 \\
GDP(-1) & -0.017908 & 0.377630 & -0.047423 \\
RESID01(-1) & -0.207164 & 0.421544 & -0.491442 \\
\hline
\end{tabular}

R-squared $=0.682$ Adjusted R-squared $=0.630$

S. E of regression $=0.017$ Durbin-Watson stat $=1.856$

Akaike info criterion $=-5.110$ Schwarz criterion $=-4.790$

* Statistically significant at 10\% level ** Statistically significant at 5\% level *** Statistically significant at $1 \%$ level

Table 5 above after regressing equation (4.1a) shows the output of error correction mechanism. The coefficients of the variables are in general significant and have the correct sign. They confirm that the short -term effects of capital formation, imports and exports are extremely important in explaining GDP growth. These variables are 1\% statistically significant in the short run in explaining GDP growth. The coefficient of capital formation growth shows (0.312) has the greatest magnitude, followed by imports growth (0.225) and finally the rate of exports (0.147). Moreover, in the short run, GDP lagged in one period is negatively correlated with GDP by a coefficient of $(-0.369)$. This implies that the current GDP is not influenced by previous GDP. In the long run the study used the lagged variables and there is no evidence indicating any significance of these variables in explaining GDP growth. The residuals from level regression estimated by OLS are included in lagged form and labelled as Resid01(-1). This represents the short-term adjustment mechanism from the equilibrium point, which is always significant, regardless of the specification employed. The significance of the lagged residuals provides strong evidence of the adequacy of an error correction framework. The coefficient shows (-0.207) is negative, as is needed for the dynamics to adjust towards the long-run equilibrium path. Looking at the estimated equation from a purely statistical point of view, it appears as though we have a good relationship with approximately $68 \%$ of the variation in the dependent variable being explained by the regressors.

Table 6 below present the results for equation (4.1b) which show that most explanatory variables are positive but differ in their significance level. The coefficient for capital formation is 0.281 , the imports ratio is 0.271 and the exports ratio is 0.009 in the short run. Among the entire explanatory variables in the short run, lagged GDP and capital formation has the greatest magnitude followed by the ratio of imports. Exports ratio is according to prior expectations with a small positive impact on GDP growth. In the long run none of the lagged variables import ratio and GDP is statistically significant in explaining GDP growth at 5 percent significance level. The estimated coefficient on the cointegration regression residual RESID02(-1) is negative at -0.266 as is expected. It appears as though we have a weak relationship with approximately $40 \%$ of the variation in the dependent variable being explained by the regressors. Overall, the models suggest that exports have positive effect in equation $4.1 \mathrm{a}$ and also in equation $4.1 \mathrm{~b}$ and that exports ratio has a small positive effect in the long run. 
Table 6: Error-correction Model based on equation (4.1b)

\begin{tabular}{llll}
\hline Variable & Coefficient & Std. Error & t-statistics \\
\hline C & -0.007426 & 0.036155 & -0.205396 \\
DLOG_KINV & 0.281580 & 0.121931 & $2.309348^{* *}$ \\
DLOG_MRA & 0.271617 & 0.138582 & 1.959966 \\
DLOG_XRA & 0.009744 & 0.077714 & 0.125378 \\
DLOG_GDP(-1) & -0.427720 & 0.121725 & $-3.513824^{* *}$ \\
MRA(-1) & -0.043717 & 0.069357 & -0.630318 \\
XRA(-1) & 0.027233 & 0.045363 & 0.600331 \\
GDP(-1) & 0.022295 & 0.070732 & 0.315207 \\
RESID02(-1) & -0.266303 & 0.149663 & -1.779356 \\
\hline
\end{tabular}

R-squared $=0.4075$ Adjusted R-squared $=0.3108$

S.E of regression $=0.02391$ Durbin-Watson stat $=1.940$

Akaike info criterion $=-4.486$ Schwarz criterion $=-4.166$

* Statistically significant at 10\% level ** Statistically significant at 5\% level *** Statistically significant at $1 \%$ level

Granger causality results: Since there is cointegration between trade openness and GDP growth, the next step is to test for the direction of causality using a simple Granger causality test by estimating the bivariate autoregressive processes for GDP and trade openness. The objective of this exercise is to empirically test the trade openness led growth (TLG) hypothesis for South Africa. The presence of a cointegrating vector allows for the use of a vector error correction model to test causality. The results of the Granger causality test are presented in the following Table.

Table 7: Granger causality results

\begin{tabular}{llll}
\hline Null hypothesis & Obs & F statistics & Probability \\
\hline DLOG_M does not Granger Cause DLOG_GDP & 56 & 0.51455 & 0.67418 \\
DLOG_GDP does not Granger Cause DLOG_M & 56 & 3.98371 & $0.01285^{* *}$ \\
DLOG_MRA does not Granger Cause DLOG_GDP & 56 & 0.41239 & 0.74483 \\
DLOG_GDP does not Granger Cause DLOG_MRA & 56 & 0.80765 & 0.49573 \\
DLOG_X does not Granger Cause DLOG_GDP & 56 & 0.94170 & 0.42774 \\
DLOG_GDP does not Granger Cause DLOG_X & 56 & 1.18655 & 0.32456 \\
DLOG_XRA does not Granger Cause DLOG_GDP & 56 & 0.04321 & 0.98791 \\
DLOG_GDP does not Granger Cause DLOG_XRA & 56 & 0.23821 & 0.86928 \\
\hline
\end{tabular}

In all the cases in Tables 7, the most reported probabilities are greater than 0.05 significant levels. There is no evidence found to suggest that real exports and ratio of export Granger cause GDP growth. In testing Granger causality test only 3 lags are employed. The hypothesis that GDP does not granger causes imports to be rejected at $5 \%$ significance level. The evidence in this section does not provide much support for the causality relationship between trade openness measures and GDP growth. There is weak evidence suggesting that the direction of causality runs from GDP to exports, which further strengthens the case against the ELG hypothesis for the South Africa.

\section{Discussion and Recommendation}

The current study attempts to make some contribution to international trade as a field by analysing and explaining the causal relationship between trade openness and GDP growth in South Africa since the ushering in of democracy in 1994. The importance of the study is to hinges on its ability to help the Department of Trade and Industry (DTI) in their policy making with regard to export promotions. The study confirms the relationship between trade openness and GDP growth by employing Johansen cointegration. Also in applying causality test it was found that in all trade openness measures that are used, there is weak evidence suggesting causality from GDP to exports or vice versa. The only hypothesis found is GDP growth-led import growth which is supported by the empirical findings in South Africa at 5 percent significant level. The proceeded findings they are in line with studies of Gutie'rrez de Pineres and Cantavella-Jorda (2007), Sinoha-Lopete (2006) and Sharma \& Panagiotidis (2004) where they found that ELG hypothesis receives weak support. Finally, as the study confirms the long run cointegration between trade openness and GDP growth in South Africa, these results are expected from economic theory, that an increase in exports leads to an increase in GDP. It is important that for South African government to consider that trade openness promotion strategies. In fact, openness stimulates economic growth on both 
the demand and supply side. South Africa should use policies that make exports more competitive in order to get access to international markets. For this rationale, increasing the share of and diversifying of total exports and imports should be considered as top priorities.

Suggestions for Future Research: It is suggested that future investigations should exclude imports and exports from GDP, and this could help identify any prospective relationship between trade openness and GDP growth and would be useful for future policy decisions. Another important issue for further investigation is the role of exports or imports in individual sectors of the economy. This would allow the formulation of policies specific to individual sectors in the South African economy.

\section{Reference}

Anderson, J. (2007). Is China Export-Led? Global Economics Research. Asia Hong Kong, UBS Investment Research, 27 September 2007

Awokuse, T. 0. (2006). Export-led growth and the Japanese economy: evidence from VAR and directed acyclic graphs. Applied Economics, 38, 593-602

Awokuse, T. 0. (2008). Trade openness and economic growth: is growth export-led or import-led? Applied Economics, 40, 161-173

Balaguer, J. \& Cantavella-Jorda, M. (2004). Structural change in exports and economic growth: cointegration and causality analysis for Spain (1961-2000). Applied Economics, 36, 473-477

Bekõ, J. (2003). Causality Analysis of Exports and Economic Growth, Aggregate and Sectoral Results for Slovenia. Eastern European Economics, 41(6), 70-92.

De Jager, J. L. W. (2004). Aspects of growth empirics in South Africa. Doctor commerce (Economics).Faculty of economics and management science, University of Pretoria. November 2003.

Dickey, D. A. \& Fuller, W. A. (1981). Distribution of the estimators for autoregressive time series with a unit root. Econometrica, 49, 1057-72.

Edwards, L. \& Lawrance, R. Z. (2006). South African trade policy matters: Trade performance and trade policy. NBER working paper no. 12760 , Jel no. F1, F3

Emma, W. \& Samman, L. (2005). Openness and Growth: An empirical Investigation. Human Development Report Office Occasional Paper, Human Development Report Available at:http://hdr.undp.org/en/reports/global/hdr2005/papers/HDR2005_Samman_Emma_22.pdf

Flatters, F. \& Stern, M. (2007). Trade and Trade Policy in South Africa: Recent Trends and Future Prospects, June, Development Network Africa.

Giles, J. A. \& Williams, C. L. (2000). Export-led Growth, A survey of the Empirical Literature and Some Noncausality Results Part 2, Econometrics Working Paper EWP0002, University of Victoria, Canada, January 2000

Granger, C. W. J. (1969). Investigating causal relations by econometric models and cross-spectral methods. Econometrica, 37, 424-438.

Gutierrez de Pineres, S. A. \& Cantavella-Jorda, M. (2007). Export-led growth: are the results robust across methodologies and/or data sets? A case study of Latin America. Applied Economics, 39, 14751500

Jin, J. C. (2003). Openness and growth in North Korea: Evidence from time-series data. Review of International Economies, 11, 18-27.

Johansen, S. (1991). Estimation and Hypothesis Testing of Cointegration Vectors in Gaussian Vector Autoregressive Models. Econometrica, 59, 1551-1580.

Lewis, J. D. (2001). Reform and Opportunity: The Changing Role and Patterns of Trade in South Africa and SADC, Africa Region Working Paper Series No.14

Loots, E. (2002). Globalization and Economic Growth in South Africa: Do We Benefit From Trade and Financial Liberalization? Trade and Industrial Policy Strategy (TIPS)

Mbabazi, M. \& Morrissey, U. (2004). Trade Openness, Trade Costs and Growth: Why Sub-Saharan Africa Performs Poorly. UK Department for International Development, CREDIT Research Paper No. $06 / 08$

Rankin, N. (2001). The Export Behaviour of South African Manufacturing Firms.10-12 September, 2001 Annual Forum at Misty Hills, Muldersdrift. Centre for the Study of African Economies, University of Oxford. Trade and Industrial Policy Strategies Forum (TIPS).

Roberts, S. (2000). Understanding the Effects of Trade Policy Reform: The Case of South Africa. South African Journal of Economics, 68, 607-638. 
SARB. (2008). Monetary Policy Review, Quarterly Bulletin No 249, South African Reserve Bank. Available at:http://www.reservebank.co.za/internet/Publication.nsf/LADV/E64F25FA7CF237F2422574B 900311E3A/\$File/QBSep08.pdf

SARB. (2009). Monetary Policy Review, Quarterly Bulletin, South African Reserve Bank. Available at:http://www.reservebank.co.za/internet/Publication.nsf/LADV/F58C9120364DBE604225762 600277D0E/\$File/QBSept09.pdf

Sarkar, P. (2007). Trade Openness and Growth: Is There Any Link? September, MPRA Paper No. 4997, posted 07. November 2007. Accessed at: http://mpra.ub.unimuenchen.de/4997/1/MPRA_paper_4997.pdf

Sato, S. \& Fukushige, M. (2007). The End of Import-Led Growth? North Korean Evidence: Discussion Papers in Economics and Business. Discussion Paper 07-38.

Sharma, A. \& Panagiotidis, T. (2004). An Analysis of Exports and Growth in India: Cointegration and Causality Evidence (1971 - 2001). Review of Development Economics, 9(2), 232-248.

Sinoha-Lopete, R. (2006). Export-Led Growth in Southern Africa. A Thesis Submitted to the Graduate Faculty of the Louisiana State University and Agricultural and Mechanical College. May 2006

Strydom. (2003). International Trade and Economic Growth in South Africa. Available at:http://www.essa.org.za/download/2003Conference/Strydom\%20PDF_International\%20Tra de\%20and\%20Economic\%20Growth\%20in\%20SA.pdf

Thurlow, J. (2006). Trade liberalization and pro-poor growth in South Africa. Development Policy Research Unit (DPRU), Accelerated and Shared Growth in South Africa: Determinants, Constraints and Opportunities.

Toda, H. \& Yamamoto, T. (1995). Statistical inference in vector autoregressions with possibly integrated processes. Journal of Econometrics, 66, 225-250.

Yanikkaya, H. (2003). Trade openness and economic growth: a cross-country empirical investigation. Journal of Development Economics, 72, 57- 89 